المجلة العلمية لعلوم التربية النوعية

\title{
Study the effect of some functional foods on the liver patients in experimental animals
}

\section{Mohammed Mustafa EL-sayed,}

and

\section{Sara Mahmoud Mustafa Omar}

(Food Science Dept.-Faculty of Home Economics-Minufiya University,Egypt.)

\author{
Khaled Ali Shaheen
}

\section{ABSTRACT}

This study targeted the effect of the proportion of $7.5 \%$ Allium sativum and 5\% Echinacea on cirrhosis liver on rats fed on experimental meals after being injected by carbon tetrachloride $\left(\mathrm{Ccl}_{4}\right)$ mixed with paraffin oil. Twenty adult male albino rat, $(215 \pm 10 \mathrm{~g})$, were divided into four groups a group of the negative control group and the positive control group, while the other groups were fed on meal contained $7.5 \%$ Allium sativum and 5\% Echinacea. At the end of the experiment was determined the $\mathrm{BWG} \%, \mathrm{FI}$ and FER, were estimated liver functions, as well as lipid profiles by serum blood. The results referring to that the negative control group and the group fed on 5\% Echinacea had high significant differences $(P<0.01)$ as compared to the positive control group; regarding to the BWG\%. As for the TC, TG, HDL-c, LDL-c, VLDL-c, ALT and AST; the results showed that the negative control group and the groups fed on 7.5\% Allium sativum and 5\% Echinacea had high significant differences at $(\mathrm{P}<0.01)$ as compared to the positive control group. The study recommended that Allium sativum and Echinacea can lise as a dietary supplement to some foods for improvement the nutritive value and medical status of liver cirrhosis.

Key words: Allium sativum - Milk thistle - Echinacea - Liver cirrhosis - Treatment experimental animals - biological evaluation - chemical analysis - statistical analysis - histological examination. 


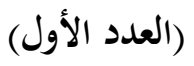

دراسة تأثير بعض الأغذية الوظيفية على مرضى الكبد فى حيوانات التجارب

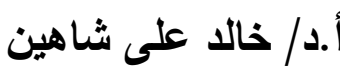

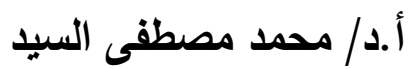

أ/ ساره محمود مصطفى عمر

(قسم التغذية وعلوم الأطعمة - كلية الإقتصاد المنزلى - جامعة المنوفية)

الملخص

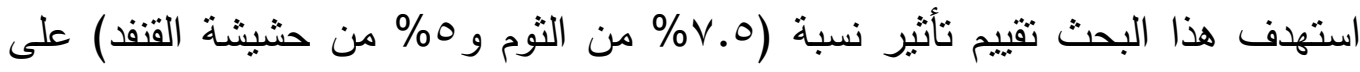

تليف الكبد في الفئران التي تغذت على وجبات تجريبية بعد حقنها برابع كلوربد الكربون مخلوطا بزيت البرافين ، وقد تم استخدام عشرين من ذكور فئران الألبينو البالغة وكان وزنها 0 ابــ. اجم، حيث تم تقسيمها إلي أربع مجموعات كانت عبارة عن المجموعة الضابطة السالبة والمجموعة الضابطة الموجبة، أما المجموعتين الأخربين تم تغذيتهما علي الوجبة الأساسية القياسية مضافا إليها النسبة المتفق عليها من الثوم وحثيشة القنفد. وفي نهاية التجربة تم حساب النسبة المئوية للزيادة في وزن الجسم والزيادة فى الوزن ومعدل كفاءة الغذاء، كما تم تقدير وظائف الكبد، وكذا دلالات الدهون عن طريق سيرم الدم. وقد أوضحت النتائج المتحصل عليها أن المجموعة الضابطة السالبة والمجموعة التى تغذت على 0\% من حشيشة القنفد فروقا معنوية عند مستوى (P<0.01) مقارنة بالمجموعة الضابطة الموجبة فيما يتعلق بالنسبة المئوية لوزن الجسم المكتسب، فى حين أن المجموعة التى تغذت على 0.\% من الثوم أظهرت فروقا معنوية عند مستوى بالمقارنة بالمجموعة الضابطة الموجبة. أما بالنسبة للكوليستيرول الكلي والدهون الثلاثية، البروتينات الدهنية عالية الكثافة، البروتينات الدهنية منخفضة الكثافة، البروتينات الدهنية منخفضة الكثافة جدا، ALT و AST أظهرت النتائج أن كلا من المجموعة الضابطة السالبة

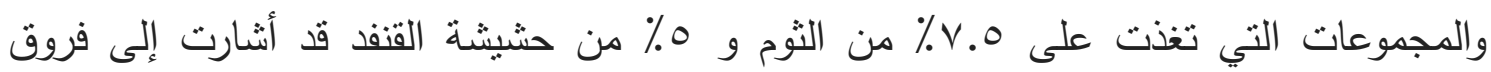
معنوية ذات دلالة إحصائية عالية (P>01>01) بالمقارنة بالمجموعة الضابطة الموجبة. وتوصى الدراسة بضرورة تتاول الثوم وحشيشة القنف حتى نتجنب تليف الكبد، مع إجراء أبحاث مستقبلية وهستوباثولوجية لمعرفة سلامة الأثر الناتج لإستعمال الثوم وحشيشة القنف . الكلمات الكثافة:

الثوم - القرطم - حشيثة القفد - تليف الكبد - العلاج - حيوانات التجارب - التقييم البيولوجى - التحليل الكيميائى - التحليل الإحصائى - الإختبارات الهستوباثولوجية. 


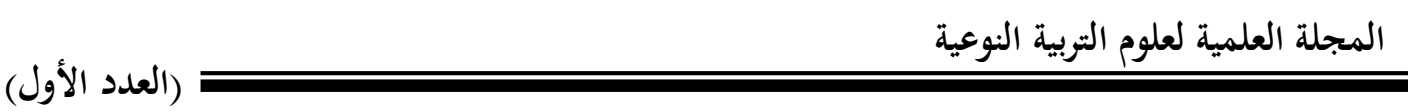

\section{INTRODUCTION}

The liver is the largest organ in the body. A human liver normally weighs $1.44-1.66 \mathrm{~kg}(3.2-3.7 \mathrm{lb}$.). It was found high in the upper abdomen, behind the ribs. It contains four sections called lobes. Within each lobe, lobules contain liver cells and passageways for blood circulation, called sinusoids. It is within the lobules that the specialized liver cells transform chemical substances into nutrients; the body can use or neutralizes potential toxins to protect the body from damage. The liver also has a remarkable power to regenerate itself. However, there are illnesses that can cause permanent and irreversible damage to the liver. The liver being the most active gland of the body secretes about $600-$ $800 \mathrm{ml}$ of bile daily. Liver diseases may have a number of causes: infectious agents, toxic agents, dietary agents, storage diseases and congenital disorders (ADA, 2000); (Zakim et al., 2002) and (Cotran et al., 2005). The liver is very complex organ and has many functions (Jackson, 2002). Cirrhosis is a result of advanced liver disease. It is characterized by replacement of liver tissue by fibrosis (scar tissue) and regenerative nodules (lumps that occur due to attempted repair of damaged tissue). These changes lead to loss of liver function. Cirrhosis is most commonly caused by alcoholism, hepatitis $B$ and hepatitis $C$, and fatty liver disease, but has many other possible causes. Some cases are idiopathic (of unknown cause) (Iredale, 2003). Herbal medicines are now used by up to $50 \%$ of the Western population, in a substantial minority of instances for the treatment or prevention of liver cirrhosis. Herbal preparations contain many bioactive compounds with potentially deleterious as well as beneficial effects. There is clearly a need for greater education of patients, doctors and nutritionists about herbal therapy, for legislation to control the quality of herbal preparations, and in particular for further randomized controlled trials to establish the value and 
المجلة العلمية لعلوم التربية النوعية

safety of such preparations in digestive, other disorders and liver cirrhosis (Langmead and Rampton, 2001).

\section{MATERIALS AND METHODS}

Materials:

1-Echinacea (raw) was purchased from Surour Company for herbs and species store, Tanta, Gharbia, Egypt, and Echinacea was grinding in the house; but garlic (Allium sativum) powder was purchased in ready.

2-Basal diet was installed after purchased its ingredients from ALGomhoriya Co., Tanta -Gharbia - Egypt.

3-Minerals and vitamins mixtures were purchased from $\mathrm{AL}-$ Gomhoriya Co., Tanta - Gharbia - Egypt.

\section{Animals:}

Twenty Sprague-Dawley white male albino rats, each $(215 \pm 10 \mathrm{~g})$, were used in this investigation obtained from serum and vaccine center. All rats were housed in group cages under conditions of controlled temperature $\left(22-24^{\circ} \mathrm{C}\right)$ and illumination $(12-\mathrm{h}$ light cycle starting at $6 \mathrm{AM})$ for at least six days before experiments.

\section{Animals and experimental design:}

Rats were housed individually in well aerated cages under hygienic laboratory conditions. Animals were housed of Institute of ophthalmology, Cairo University, and fed for one week on standard died for adaptation before the beginning of the experiment according to (NRC, 1995). Rats were divided into 4 groups, every 5 rats in each group fed on certain diet for 28 days as following:

Group (1) (Negative or normal group) (-Ve): Fed on basal diet only, as a negative control. 


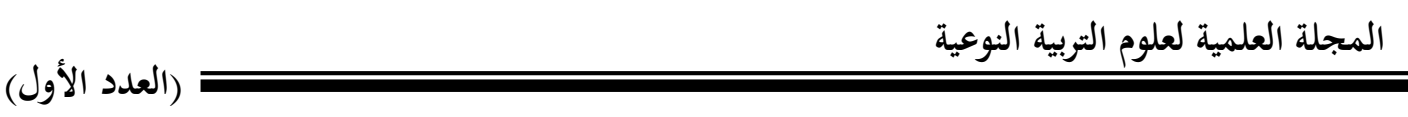

Group (2) (Positive group) (+Ve): Fed on basal diet after injection with $\left(\mathrm{CCl}_{4}\right)$, as a positive control and the infection continues throughout the period of the experiment.

Group (3) (Treatment group): Liver cirrhosis groups, fed on basal diet plus $7.5 \%$ Allium sativum and 5\% Echinacea.

\section{Methods:}

Biological evaluation:

During the experimental period, the consumed diet was recorded everyday, feed intake $(\mathrm{Fl})$, and body weight was recorded every three day. Biological evaluation of the different diets was carried out by determination of body weight gain, percentage of body weight gain and feed efficiency ratio (Chapman et al., 1959), using the following formulas:

Body weight gain $($ BWG) $(\mathbf{g})=$ Final weight - Initial weigh

Body weight gain $(\mathrm{BWG} \%)=\frac{\text { Final weight }- \text { Initial weight }}{\text { Initial weight }} \times 100$

Feed efficiency ratio $($ FER $)=\frac{\text { Body weight gain }}{\text { Feed intake }}$

\section{Biochemical analysis:}

At the end of the experiment, the rats were fasted overnight and serially anesthetized with diethyl ether. Blood was collected in clean dry centrifuge tubes from hepatic portal vein, this tubes containing 3.1\% sodium citrate solution $(1: 10 \mathrm{v} / \mathrm{v})$ to prepare serum and plasma, respectively (Jacobs et al., 2001) and (Malhotra, 2003). Blood samples were centrifuged for 15 minutes at $3000 \mathrm{rpm}$ to separate the serum. Serum was carefully separated and transferred into dry clean ebendorf 


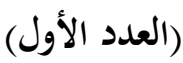

tubes and kept frozen at $20 \dot{c}$ until analysis (Turkdogan et al., 2003). Serum total cholesterol, triglyceride (TG) and high density lipoprotein cholesterol (HDL-c) were determined using enzymatic colorimetric methods of Richmond, (1973) and Allain, (1974); Fassati and Principe, (1982) and Burstein, (1970) and Lopez, (1977) respectively. The determination of low density lipoprotein cholesterol (LDL-c) was calculated as $\mathrm{mg} / \mathrm{dl}$ (Castelli, 1977) equation:

$$
\text { LDL-c }(\mathbf{m g} / \mathbf{d l})=\text { Total cholesterol }-[\mathrm{HDL}-\mathrm{c}+\mathrm{VLDL}-\mathrm{c}]
$$

When very low density lipoprotein cholesterol (VLDL-c) was carried out according to Srivastava et al.,(2002) equation:

$$
\text { VLDL-c }(\mathbf{m g} / \mathbf{d l})=\text { Triglycerides } / 5
$$

Serum aspartate and alanine amino transferase (AST and ALT) were determined using enzymatic colorimetric methods (Reitman and Frankel, 1957).

\section{Statistical analysis:}

Statistical analysis was performed by using computer program, Statistical Package for Social Science and compared with each other using the suitable tests (SPSS, 1998).

\section{RESULTS AND DISCUSSION}

Table (1) point to the effect of $7.5 \%$ Allium sativum and $5 \%$ Echinacea on percentage body weight gain (BWG \%); feed intake (FI) and feed efficiency ratio (FER) in rats pretreated with $\mathrm{CCl}_{4}$. As shown that the negative control group and group fed on 5\% Echinacea showed high significant differences $(\mathrm{P}<0.01)$, when compared with positive control. However, group fed on $7.5 \%$ of Allium sativum pointed to significant difference $(P<0.05)$, when compared with positive control. The same table illustrated for feed intake $(\mathrm{FI})$ that the negative control showed a significant differences $(P<0.05)$, when compared with positive control. 


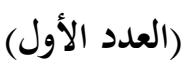

However, the groups fed on $7.5 \%$ Allium sativum and 5\% Echinacea were showed a high significant differences $(P<0.01)$, when compared with positive control. Regarding feed efficiency ratio (FER), it was found from data of the same table that the negative control showed a high significant differences $(P<0.01)$, when compared with positive control; while the group was fed on 5\% Echinacea was refer to a significant differences $(P<$ $0.05)$, when compared with positive control. These results were agreeable with Zaina, (2004) were reported that many patients with liver cirrhosis are suffering from also lose weight. As well as, Feranchek, (2005) were showed that the liver cirrhosis can lead to malnutrition, and the major causes of malnutrition in patients with liver cirrhosis are poor dietary intake. Mal-digestion, mal-absorption, and abnormalities in the metabolism and storage of micro and macro nutrients are too leading to malnutrition in patients with liver cirrhosis. This report was supported my study based on the results.

Table (1): Effects of 7.5\% Allium sativum and 5\% Echinacea on BWG $\%$; $\mathrm{FI}$ and $\mathrm{FER}$ in rats pretreated with $\mathrm{CCl}_{4}$

\begin{tabular}{|c|c|c|c|}
\hline Groups & BWG \% & FI g/ day & FER \\
\hline- Ve & $3.14 \pm 0.86^{\mathrm{b}}$ & $225.3 \pm 8.1^{\mathrm{a}}$ & $0.03 \pm 0.01^{\mathrm{b}}$ \\
\hline+ Ve & $-21.44 \pm 1.09^{\mathrm{c}}$ & $203.2 \pm 2.3^{\mathrm{c}}$ & $-0.04 \pm 0.01^{\mathrm{c}}$ \\
\hline $\begin{array}{c}7.5 \% \text { Allium } \\
\text { sativum }\end{array}$ & $4.18 \pm 0.74^{\mathrm{a}}$ & $210.4 \pm 3.7^{\mathrm{b}}$ & $0.04 \pm 0.009^{\mathrm{bc}}$ \\
\hline $\mathbf{5 \% \text { Echinacea }}$ & $3.72 \pm 0.90^{\mathrm{b}}$ & $216.1 \pm 3.5^{\mathrm{b}}$ & $0.06 \pm 0.02^{\mathrm{a}}$ \\
\hline
\end{tabular}

${ }^{a}$ Differences are significant at $5 \%(P<0.05)$

${ }^{\mathrm{b}}$ Differences are high significant at $1 \%(\mathrm{P}<0.01)$

${ }^{c}$ Differences are very high significant at $0.1 \%(P<0.001)$

Control -ve: Rats were fed on basal diet only

Control +ve: Rats were pretreated with $\mathrm{CCl}_{4}$ and fed on basal diet

Allium sativum: Fed on basal diet plus $7.5 \%$ Allium sativum

Echinacea: Fed on basal diet plus 5.0\% Echinacea 


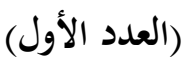

Table (2) revealed the effect of $7.5 \%$ Allium sativum and $5 \%$ Echinacea on total cholesterol (TC) and triglycerides (TG) in rats pretreated with $\mathrm{CCl}_{4}$. The negative control; group fed on $7.5 \%$ Allium sativum and 5\% Echinacea showed to a high significant differences $(\mathrm{P}<$ 0.01 ), comparing to positive control for total cholesterol (TC). As for serum triglycerides (TG) from the same table, the control negative; group fed on $7.5 \%$ Allium sativum and $5 \%$ of Echinacea were referred to a high significant differences $\mathrm{P}<0.01$, comparing to control positive. Rombeau and Rolandelli, (2001) reported that the liver cirrhosis lead to increase total cholesterol (TC) and triglycerides (TG), and fat maldigestion, mal-absorption. From this results, it was be observe that all diets were had favorable effects on serum total cholesterol and triglycerides. These results were supported with Blumenthal et al., (2000); Sheppard, (2005) and Singh and Panda, (2005) and agreeable with our results.

Table (2): Effects of 7.5\% Allium sativum and 5\% Echinacea on TC and TG in rats pretreated with $\mathrm{CCl}_{4}$

\begin{tabular}{|c|c|c|}
\hline Groups & TC $\mathbf{~ m g} / \mathrm{dl}$ & TG $\mathbf{~ m g} / \mathbf{d l}$ \\
\hline$-\mathbf{V e}$ & $129.50 \pm 2.00^{\mathrm{b}}$ & $96.10 \pm 1.20^{\mathrm{b}}$ \\
\hline+ Ve & $224.60 \pm 3.20^{\mathrm{a}}$ & $154.40 \pm 3.40^{\mathrm{a}}$ \\
\hline $\begin{array}{c}7.5 \% \text { Allium } \\
\text { sativum }\end{array}$ & $127.90 \pm 0.78^{\mathrm{b}}$ & $95.00 \pm 1.70^{\mathrm{b}}$ \\
\hline $\mathbf{5 \% \text { Echinacea }}$ & $128.50 \pm 0.69^{\mathrm{b}}$ & $95.30 \pm 1.50^{\mathrm{b}}$ \\
\hline
\end{tabular}

${ }^{a}$ Differences are significant at $5 \%(P<0.05)$

${ }^{\mathrm{b}}$ Differences are high significant at $1 \%(\mathrm{P}<0.01)$

${ }^{c}$ Differences are very high significant at $0.1 \%(P<0.001)$

Control -ve: Rats were fed on basal diet only

Control +ve: Rats were pretreated with $\mathrm{CCl}_{4}$ and fed on basal diet 


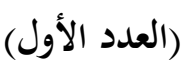

Allium sativum: Fed on basal diet plus $7.5 \%$ Allium sativum

Echinacea: Fed on basal diet plus 5.0\% Echinacea

Table (3) illustrated the effect of $7.5 \%$ Allium sativum and $5 \%$ Echinacea on serum lipoproteins $[\mathrm{HDL}-\mathrm{C}$; $\mathrm{LDL}-\mathrm{C}$ and $\mathrm{VLDL}-\mathrm{C}]$ in rats pretreated with $\mathrm{CCl}_{4}$. From the outcomes in table (3) the negative control group and groups fed on $7.5 \%$ llium sativum and $5 \%$ Echinacea had a high significant differences at $(P<0.01)$ as compared to the positive control group. Rombeau and Rolandelli, (2001) reported that the liver cirrhosis lead to increase serum lipoproteins synthesis, and fat maldigestion, mal-absorption. From this results, it was be observed that all diets had favorable effects on serum lipoproteins. These results were supported with Blumenthal et al., (2000); Sheppard, (2005) and Singh and Panda, (2005) and agreeable with our results.

Table (3): Effects of 7.5\% Allium sativum and 5\% Echinacea on serum lipoproteins [HDL-c; LDL-c and VLDL-c] in rats pretreated with $\mathrm{CCl}_{4}$

\begin{tabular}{|c|c|c|c|}
\hline Groups & HDL-c mg/dl & LDL-c mg/dl & V.LDL-c mg/dl \\
\hline- Ve & $56.30 \pm 1.70^{\mathrm{b}}$ & $63.20 \pm 0.89^{\mathrm{b}}$ & $18.30 \pm 0.78^{\mathrm{b}}$ \\
\hline+ Ve & $80.40 \pm 4.10^{\mathrm{a}}$ & $90.60 \pm 4.03^{\mathrm{a}}$ & $39.80 \pm 3.70^{\mathrm{a}}$ \\
\hline $\begin{array}{c}7.5 \% \text { Allium } \\
\text { sativum }\end{array}$ & $54.00 \pm 1.70^{\mathrm{b}}$ & $64.00 \pm 1.20^{\mathrm{b}}$ & $19.00 \pm 1.70^{\mathrm{b}}$ \\
\hline $\mathbf{5 \% \text { Echinacea }}$ & $55.30 \pm 2.30^{\mathrm{b}}$ & $64.50 \pm 1.60^{\mathrm{b}}$ & $19.50 \pm 0.99^{\mathrm{b}}$ \\
\hline
\end{tabular}

${ }^{a}$ Differences are significant at $5 \%(P<0.05)$

${ }^{b}$ Differences are high significant at $1 \%(P<0.01)$

${ }^{c}$ Differences are very high significant at $0.1 \%(P<0.001)$

Control -ve: Rats were fed on basal diet only

Control +ve: Rats were pretreated with $\mathrm{CCl}_{4}$ and fed on basal diet

Allium sativum: Fed on basal diet plus $7.5 \%$ Allium sativum

Echinacea: Fed on basal diet plus 5.0\% Echinacea

Table (4) pointed to the effect of $7.5 \%$ Allium sativum and $5 \%$ Echinacea on serum liver enzymes GOT (AST) and GPT (ALT) in rats were pretreated with $\mathrm{CCl}_{4}$. From this table, the results were illustrated that the negative control and all diets showed a high significant differences $(P$ 


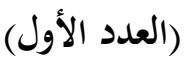

$<0.01$ ), when compared with positive control for GOT (AST) and GPT (ALT). Gaw et al., (2004) were reported that the higher activities of aminotransferase enzymes S.GOT (AST) and S.GPT (ALT) were indicated to hepatocellular damage. From these results, it was observed that S.GOT (AST) level of positive control was higher than all diets and negative control. Whereas, S.GPT (ALT) level of all diets and negative control were higher than positive control. All diets had very clear effect on S.GOT (AST) and S.GPT (ALT). These results were agreeable with Weiss and Fintelmann, (2000) and Singh and Panda, (2005).

Table (4): Effects of 7.5\% Allium sativum and $5 \%$ Echinacea on [S.GOT (AST)] and [S.GPT (ALT)] in rats were pretreated with $\mathrm{CCl}_{4}$

\begin{tabular}{|c|c|c|}
\hline Groups & S.GOT [AST] u/ml & S.GPT [ALT] u/ml \\
\hline- Ve & $33.20 \pm 2.40^{\mathrm{b}}$ & $32.80 \pm 2.60^{\mathrm{b}}$ \\
\hline+ Ve & $65.20 \pm 3.90^{\mathrm{a}}$ & $74.20 \pm 2.80^{\mathrm{a}}$ \\
\hline $\begin{array}{c}7.5 \% \text { Allium } \\
\text { sativum }\end{array}$ & $35.20 \pm 4.30^{\mathrm{b}}$ & $33.60 \pm 2.90^{\mathrm{b}}$ \\
\hline $\mathbf{5 \% \text { Echinacea }}$ & $34.20 \pm 3.20^{\mathrm{b}}$ & $32.90 \pm 2.10^{\mathrm{b}}$ \\
\hline
\end{tabular}

${ }^{a}$ Differences are significant at $5 \%(P<0.05)$

${ }^{\mathrm{b}}$ Differences are high significant at $1 \%(\mathrm{P}<0.01)$

${ }^{\mathrm{C}}$ Differences are very high significant at $0.1 \%(P<0.001)$

Control -ve: Rats were fed on basal diet only

Control +ve: Rats were pretreated with $\mathrm{CCl}_{4}$ and fed on basal diet

Allium sativum: Fed on basal diet plus $7.5 \%$ Allium sativum

Echinacea: Fed on basal diet plus 5.0\% Echinacea 
المجلة العلمية لعلوم التربية النوعية

\section{References}

Allain, C.C. (1974): Determination of serum total cholesterol: Clin. Chem.; (20): 470 .

American Dietetic Association (2000): Manual of clinical dietetic. $6^{\text {Th }}$ ed. Chicago; USA; Biochemistry; CBC Publishers and Distributors: Biochem; Res.

Blumenthal, M.; Goldberg, A. and Brinckmann, J. (2000): Herbal medicine; expanded commission e monographs. Newton, MA: Integrative Medicine Communications; 257-263.

Burstein, M. (1970): Determination of serum high density lipoprotein cholesterol: Lipid Res.11, 583.

Castelli, W. (1977): Determination of serum low density lipoprotein cholesterol. Sclavo; Diagnosis made in Italy, circulation. 55: 767-769.

Chapman, D.G.; Castilla, R. and Champbell, J.A. (1959): Evaluation of protein in food. I.A. Method for the determination of protein efficiency ratio: Can. J.; Biochemistry. Physiology, 37: 679-686.

Cotran, R, S.; Kumar, V, F, Nelson, N. F, Robbins, Stanley L.; Abbas, and Abul, K. (2005): Robbins and Cotran pathologic Basis of Disease ( $7^{\text {th }}$ ed.) St. Louis, MO: Elsevier Saunders; p. 878.

Fassati, P. and Prencipe, L. (1982): Determination of serum triglycerides: Clin. Chem; (28): 2077.

Feranchek, A. (2005): Comparison of indices of vitamin A status in children with chronic liver disease. Hepatology 42: 782-792.

Gaw, A.; Murphy, M.J.; Cowan, R.A.O.; Reilly, D.J.; Stewart, M.J. and Sheppard, J. (2004): Clinical biochemistry. $3^{\text {rd }}$ edition: Elsevier limited: Churchill Livingstone.

Iredale, J.P. (2003): Cirrhosis: new research provides a basis for rational and targeted treatments. BMJ 327 (7407): 143-7. 


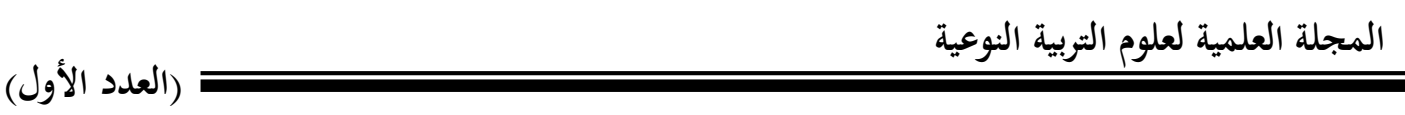

Jackson, F. (2002): Liver transplant: Chek Med Systems $®$, Inc.; Jackson Gastroenterology: 423 North 21 Streets, Suite 100 Camp Hill, PA 17011 .

Jacobs, D.S.; Oxley, D.K. and Demott, W.R. (2001): Laboratory Tests Handbook: Lexi-Comp, Inc.

Langmead, L. and Rampton, D.S. (2001): Review article: herbal treatment in gastrointestinal and liver disease-benefits and dangers. Aliment Pharmacol. Ther, 15 (9): 1239-1252.

Lopez, M.F. (1977): Determination of serum high density lipoprotein cholesterol: Clin. Chem, (23): 882.

Malhotra, V.K. (2003): Practical Biochemistry for Students, $4^{\text {th }}$ edition, Jaypee Brothers Medical Publishers (P) LTD.; New Delhi-India.

National Research Council (1995): Nutrient Requirements of Laboratory Animals. Fourth Revised Edition National Research Council, National Academy Press, PP. 29-30; Washington DC.

Reitman, A. and Frankel, S. (1957): Determination of serum glutamate oxaloacetate transaminase (GOT) and serum glutamate pyruvate transaminase (GPT): Am. J. Clin. Path., 28: 56.

Richmond, W. (1973): Determination of serum total cholesterol: Clin. Chem.; (19): 1350.

Rombeau, J.L. and Rolandelli, R.H. (2001): Clinical Nutrition Potential: $3^{\text {rd }}$ ed. W.B. Saunders Company.

Sheppard, H.S. (2005): The aromatherapy practitioner reference; the illustrated encyclopedia of essential oil. Biochem; Res.10 (1): 62-73.

Singh, M.P. and Panda, H. (2005): Medical herbs with their formulations. Vol.1; Daya Publishing House: Delhi-India.

SPSS (1998): Statistical package for social science, computer software, Ver.10. SPSS Company. London, UK. Statistics version 1.0 copyright 1995: Analytical software windows version 95. 


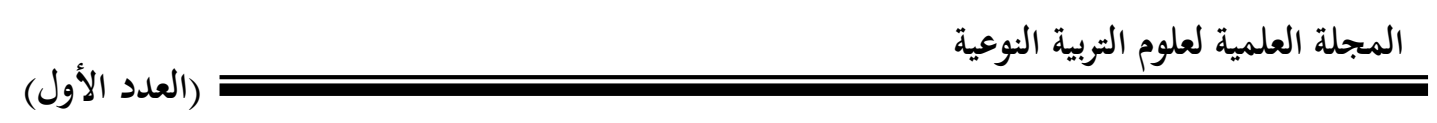

Srivastava, L.M.; Das, N. and Sinha, S. (2002): Essentials of practical biochemistry; $\mathrm{CBC}$ publishers and distributors: Biochem; Res.

Turkdogan, M.K.; Ozbek, H.; Yener, Z.; Tuncer, I.; Uygan, I. and Ceylan, E. (2003): The role of Urtica dioica and Nigella Sativa in the prevention of $\mathrm{Ccl} 4$ induced hepato-toxicity in rats: Division of Gastroenterology; Faculty of Medicine, Yuzuncu Yil University; Van Turkey. Phytother; Res.; 17 (8): 942-946.

Weiss, R.F. and Fintelmann, V. (2000): Herbal medicine: $2^{\text {nd }}$ edition; Thieme Stuttgart; New York; USA.

Zaina, F.E. (2004): Prevalence of malnutrition in liver transplant candidates. Transplant Proc 36: 923-925.

Zakim; David; Boyer and Thomas D. (2002): Hepatology: A Textbook of Liver Disease $\left(4^{\text {th }}\right.$ ed.). 